УДК 656.2

\title{
ПЕРЕДУМОВИ РОЗРОБЛЕННЯ НОВИХ МЕТОДІВ УПРАВЛІННЯ ПРОПУСКНОЮ СПРОМОЖНІСТЮ ЗАЛІЗНИЧНОӤ ІНФРАСТРУКТУРИ В УМОВАХ РЕФОРМУВАННЯ ЗАЛІЗНИЧНОГО ТРАНСПОРТУ УКРАЇНИ
}

Канд. техн. наук А.В. Прохорченко

\section{ПРЕДПОСЫЛКИ РАЗРАБОТКИ НОВЫХ МЕТОДОВ УПРАВЛЕНИЯ ПРОПУСКНОЙ СПОСОБНОСТЬЮ ЖЕЛЕЗНОДОРОЖНОЙ ИНФРАСТРУКТУРЫ В УСЛОВИЯХ РЕФОРМИРОВАНИЯ ЖЕЛЕЗНОДОРОЖНОГО ТРАНСПОРТА УКРАИНЫ}

\author{
Канд. техн. наук А.В. Прохорченко \\ BACKGROUND DEVELOP NEW METHODS OF MANAGEMENT OF RAILWAY \\ INFRASTRUCTURE THROUGHPUT IN RESTRUCTURING RAILWAY UKRAINE
}

Cand. of techn. sciences A. Prokhorchenko

Стаття присвячена аналізу ефективності реформування залізнищь загального користування за моделлю функиіонування ринку залізничних перевезень на основі розділення функиій управління інфраструктурою та здійснення експлуатаційної діяльності. Обтрунтовано необхідність розроблення нових методів управління пропускною спроможністю залізничної інфраструктури в умовах реформування залізничного транспорту Украӥни.

Ключові слова: управління, залізнична інфраструктура, пропускна спроможність, реформування.

Статья посвящена анализу эффективности реформирования железных дорог общего пользования по модели функиионирования рынка железнодорожных перевозок на основе разделения функиий управления инфраструктурой и осуществления эксплуатационной деятельности. Обоснована необходимость разработки новых методов управления пропускной способностью железнодорожсной инфраструктуры в условиях реформирования железнодорожного транспорта Украиньл.

Ключевые слова: управление, железнодорожная инфраструктура, пропускная способность, реформирование.

The work is devoted to analysis of efficiency railways reform model for public rail transport market functioning on the basis of separation of infrastructure management and implementation of operational activities. An analysis of appearance market rail transportation, which is based on the sale of railway infrastructure capacity. To analyze the effectiveness of the existence of the market of access to railway infrastructure analyzed the functioning of railways in countries such as Germany and Poland. Attention is paid to the analysis of the efficiency of the largest operators managing the railway infrastructure, such as $D B$ Netz and PKP Polskie Linie Kolejowe S.A. Established in Germany and Poland for the general financial performance major companies that manage infrastructure are unprofitable but major losses are covered by government subsidies, which allows infrastructure managers to generate income and attract additional investment in infrastructure. It is proved that the process of allocation of railway infrastructure capacity becomes important, because the efficiency and speed of access to harmonize the rail network of a large number of competing companies depend on the financial results of all participants of the rail system. The necessity to develop new methods of management of railway infrastructure capacity in terms of reforming the railway transport of Ukraine.

Keywords: management, railway infrastructure, capacity, reform.

Вступ. В умовах економічної глобалізації для залізничної галузі кожної країни світу, зокрема України, головною умовою комерційної успішності $€$ необхідність 
відповідати сформованим вимогам якості транспортної послуги у глобальних торговельних мережах і виробничо-збутових системах [1]. На даний час світовий ринок торгівлі зростає все більше, формуючи нові мережі ланцюгів постачання від виробників до споживачів через використання всіх видів транспорту. Причому майже $80 \%$ перевезень вантажів здійснюється морським транспортом [2]. В умовах інтеграційних процесів у сфері вантажних перевезень швидко розвивається транспортно-логістичний ринок, у якому величина тарифу на перевезення і надійність часу прибуття в пункт призначення в цілому $\epsilon$ найбільш важливими факторами, які визначають якість транспортної послуги.

Аналіз світових тенденцій розвитку ринку вантажних перевезень та існуючого стану залізничного транспорту України показав невідповідність рівня якості транспортної послуги встановленим вимогам на глобальному ринку перевезень. Одним із напрямків підвищення якості транспортних послуг для залізничного транспорту є лібералізація ринку вантажних залізничних перевезень.

Визначення мети та задачі дослідження. Дана стаття має на меті проаналізувати ефективність реформування залізниць загального користування за моделлю функціонування ринку залізничних перевезень на основі розділення функцій управління інфраструктурою та здійснення експлуатаційної діяльності. Це дасть змогу обгрунтувати необхідність розроблення нових методів управління пропускною спроможністю залізничної інфраструктури в умовах реформування залізничного транспорту України.

Основна частина дослідження. Практичний досвід еволюції моделей функціонування залізниць світу свідчить, що комерційне виживання вантажних залізничних перевезень в усьому світі основане на процесі переходу від монопольного до конкурентного ринків за рахунок дерегуляції транспортної галузі $[3,4]$. В основі дерегуляції залізничної галузі $\epsilon$ створення умов для започаткування конкурентного середовища у сфері залізничних перевезень. Розвиток конкуренції реалізується за рахунок розділення функцій управління інфраструктурою та здійснення експлуатаційної діяльності. Це у свою чергу сприяє створенню незалежних компаній-перевізників, головною умовою функціонування яких $\epsilon$ принцип недискримінаційного доступу до інфраструктури. Такий підхід дає змогу реалізувати модель 3 розділеними стадіями виробництва та мережевого обслуговування, тобто коли існує інфраструктурна компанія (англ. infrastructure manager, IM), яка монопольно управляе використанням залізничної інфраструктури та надає доступ до залізничної мережі великій кількості конкуруючих компаній-перевізників (англ. railway undertakings, RU), які існують у сфері перевезень [5].

Така модель передбачає створення первинного (англ. primary market) та вторинного (англ. secondary market) ринку залізничних перевезень [6]. Ці ринки відрізняються типом товару, яким торгують на них. На первинному ринку залізничні компаніїперевізники торгують залізничними транспортними послугами, виступають як організатори та виконавці перевезень вантажів і пасажирів на комерційній основі. На вторинному ринку компанії-менеджери залізничної інфраструктури, що монопольно володіють мережею залізниць, торгують пропускною спроможністю залізничної інфраструктури, тобто продають доступ до своєї мережі шляхом виділення оператору перевезень за певну плату нитки графіка або частини пропускної спроможності залізничної мережі, яка необхідна для проходження поїзда між двома пунктами протягом певного часу. Схема взаємодії між первинним і вторинним ринками подана на рис. 1. 


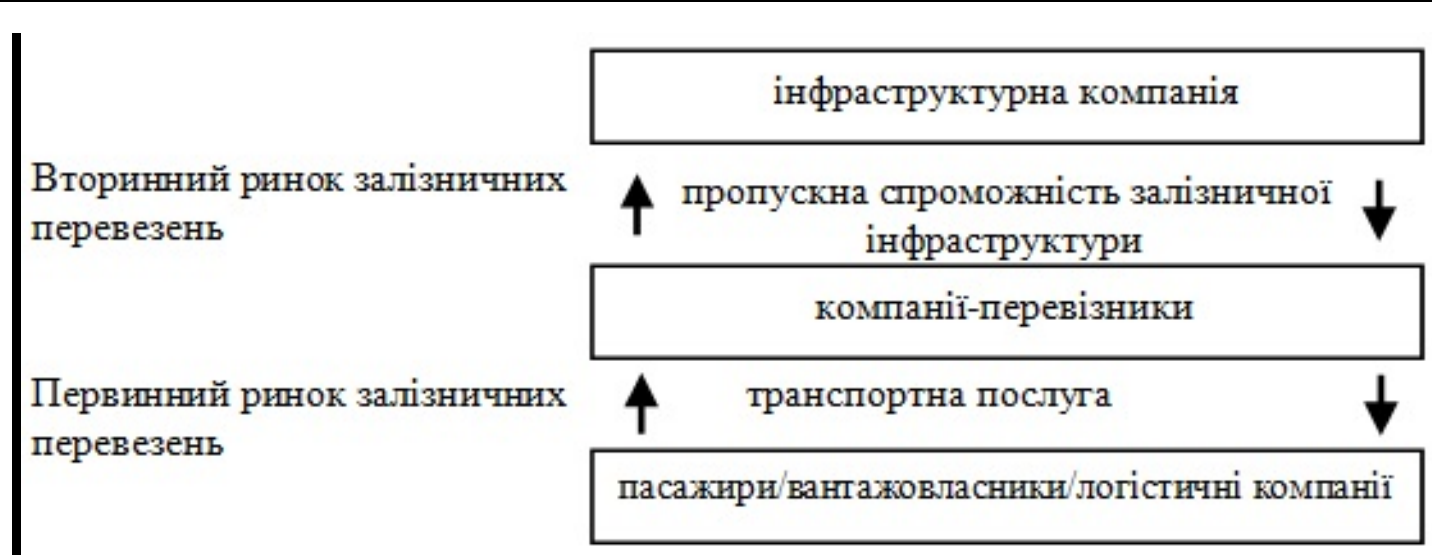

Рис. 1. Інтерференція між первинним і вторинним залізничним ринками

За таких умов, окрім найбільш поширеної моделі плати за перевезення на основі вартості за 1 ткм, яка включає всі витрати вертикально інтегрованої компанії, виникла нова система плати - за доступ до об'єктів інфраструктури, де плата за доступ до інфраструктури станцій відокремлена від плати за використання залізничних ліній. Така система взаємовідносин дає змогу створити новий сектор ринку транспортних перевезень, який оснований на продажі пропускної спроможності залізничної інфраструктури, у якому плата за використання інфраструктури залізничних ліній грунтується на вартості одного поїздо-кілометра [7].

Для аналізу ефективності існування ринку продажу доступу до залізничної інфраструктури у статті запропоновано провести аналіз функціонування залізниць таких країн, як Німеччина та Польща [8, 9]. Залізниці даних країн більш наближені за експлуатаційними показниками до залізниць України. Крім того, ринки залізничних перевезень даних країн перебувають на різних стадіях еволюції: Німеччина - стале функціонування (початок реформ у 1994 році), Польща - розвиток (початок реформ у 2000 році).

Станом на листопад 2013 року в Німеччині було видано ліцензій, що дозволяють надання транспортних послуг, близько 400 підприємствам-перевізникам [8]. Німецький залізничний ринок вважається одним із найбільших за кількістю конкурентів. Для прикладу, на залізницях Польщі функціонує 82 компаніїперевізника (англ. RU) [9].

У Німеччині компанії-перевізники на первинному ринку мають прибутковість. На вторинному ринку плата за доступ до залізничної інфраструктури від сукупного обороту всіх залізничних підприємствперевізників у вантажних залізничних перевезеннях складає лише 14 \% (рис. 2).

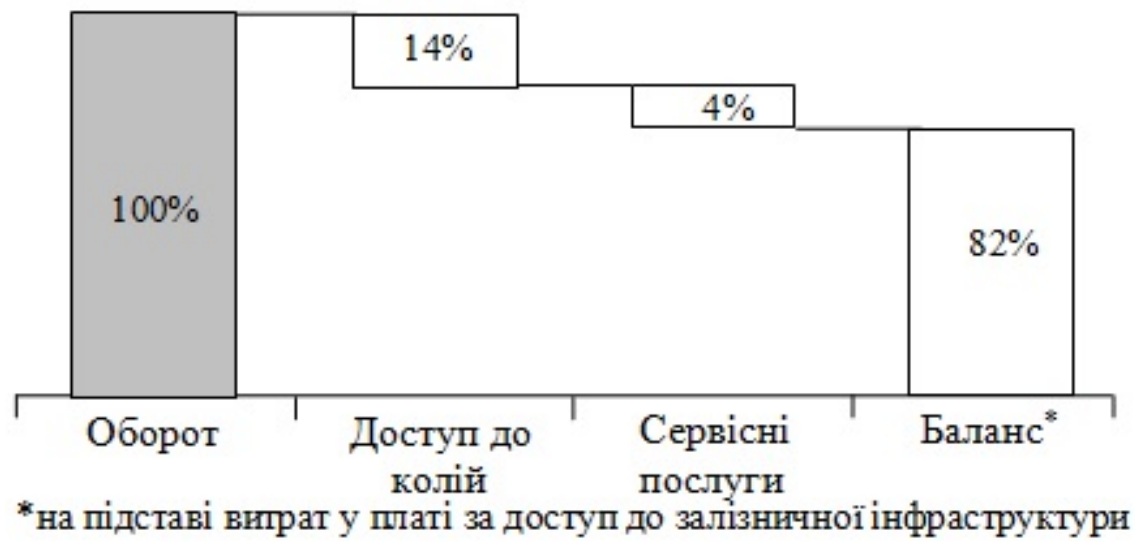

Рис. 2. Частка плати за доступ до інфраструктури у відсотках від сукупного обороту всіх залізничних підприємств у вантажних залізничних перевезеннях 


\section{Експлуатація залізниць}

Операційна ефективність компанійменеджерів інфраструктури Німеччини складає 1,06 млрд поїзд.км (англ. train-path $\mathrm{km}$ ) за 2012 рік. На залізницях Польщі найбільшою компанією-менеджером інфраструктури є РКР Polskie Linie Kolejowe S.A., що здійснює управління на 92,69\% залізничних ліній від загальної мережі. За 2012 рік PKP PLK реалізували 215005,75 тис. поїзд.км. Порівняльний аналіз показує, що рівень польських ставок на фрахт значно вищий від середнього показника по Європі, який у 2012 році був 2,70 євро 3 особи за поїздо-кілометр. Для порівняння, базова ставка за мінімальний пакет доступу до залізничної інфраструктури в Польщі у 2012 році була більша у два рази, ніж у Франції, та близько $50 \%$ вища, ніж у Німеччині (країні з великим обсягом вантажних перевезень) (рис. 3).

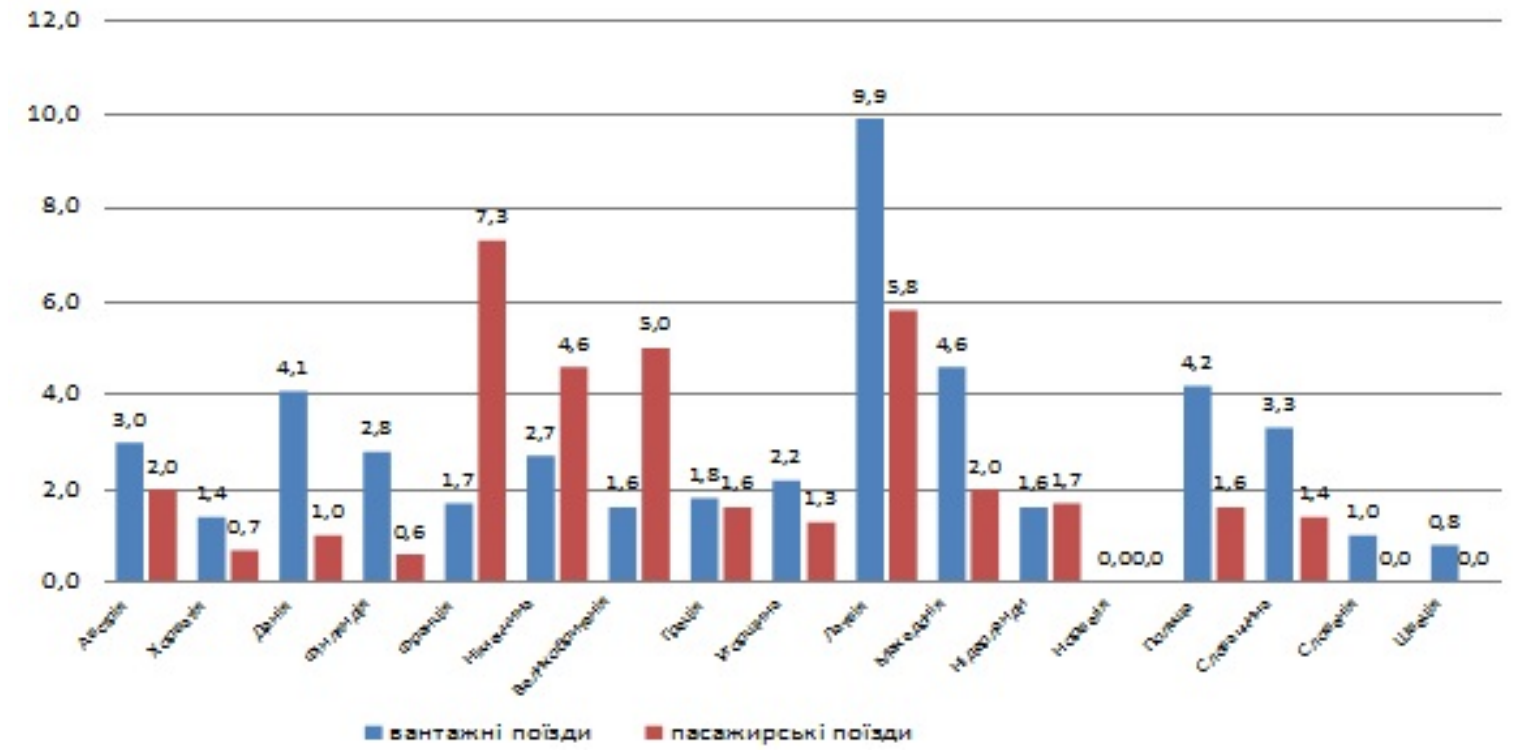

Рис. 3. Середні питомі ставки (у євро) за доступ до інфраструктури у 2012 році для вантажних і пасажирських поїздів у державах-членах ЄС

Як у Німеччині, так і у Польщі за загальними фінансовими показниками основні компанії, що управляють інфраструктурою, $є$ збитковими. Так, у Німеччині за 2012 рік дані компанії зазнали збитків на $41 \%$ від загальної вартості витрат на надання доступу до інфраструктури (рис. 4) [9]. Це пояснюється великими витратами на модернізацію та будівництво нової інфраструктури. Слід зазначити, така ситуація не $\epsilon$ критичною, так як основні збитки покриваються державними субсидіями. У цих умовах менеджери інфраструктури генерують свої доходи в першу чергу за рахунок зборів, які вони отримують за доступ до використання залізничних колій та сервісне обслуговування. Велика частина їхніх доходів - 79 \% від загальної виручки у 2012 р. складається 3 плати за доступ до інфраструктури, яка становила до 4,35 млрд євро.
У Польщі фінансові результати найбільшого оператора, що управляє інфраструктурою, також показують збитки від операційної діяльності. Так, за 2013 рік РКР Polskie Linie Kolejowe (PKP PLK) отримали збитків на суму 445,5 млн польських злотих [10]. Але сума збитку була переважно результатом витрат, які не були взяті до уваги при розрахунку ставок доступу до залізничної інфраструктури. Це, серед іншого, витрати на амортизацію за основними засобами, що фінансуються з безповоротних джерел (коштів, отриманих від $\epsilon \mathrm{C}$, Залізничного фонду місцевих органів влади та бюджетної дотації, розподіленої на фінансування інвестиційних проектів 3 модернізації інфраструктури). Якщо не враховувати вартість даних витрат, то фінансовий результат від операційної діяльності є позитивним та складає 407,4 млн злотих. 


\section{Експлуатація залізниць}

Незважаючи на деяку умовну збитковість РКР PLK, фінансування активів компанії протягом 2012-2013 років збільшується, і в першу чергу за рахунок зовнішніх надходжень, що дає змогу компанії високими темпами оновлювати свою інфраструктуру (рис. 5).

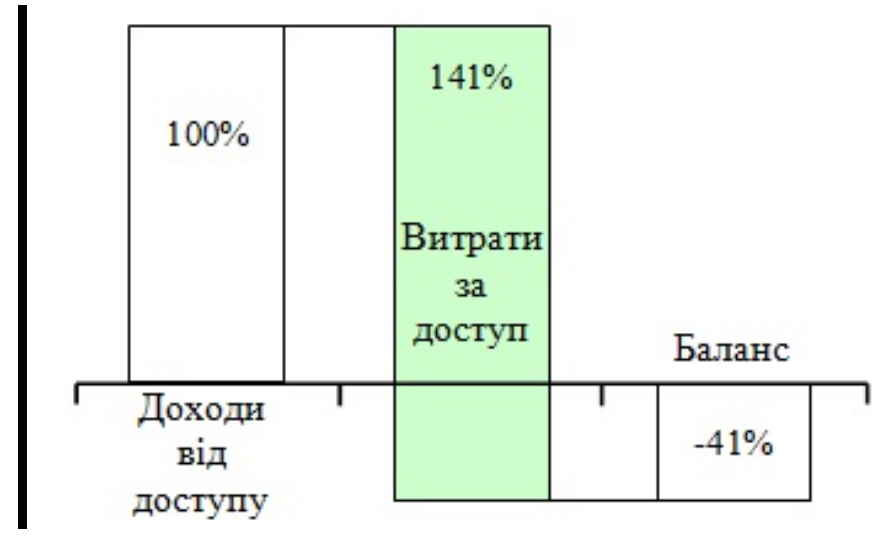

Рис. 4. Доходи, витрати і фінансові результати компаній, що управляють інфраструктурою залізниць Німеччини за 2012 рік

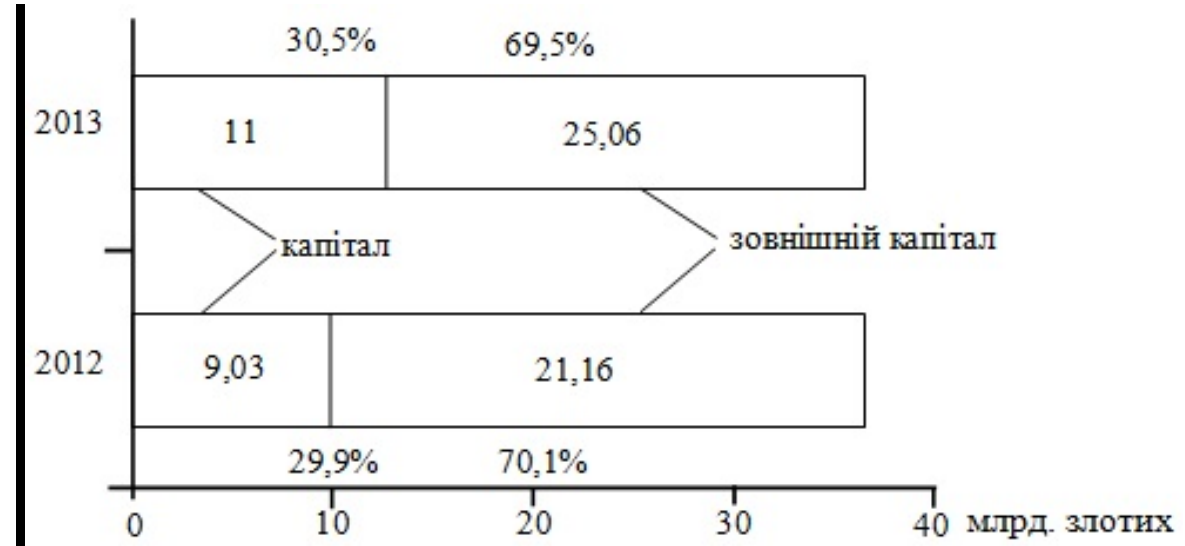

Рис. 5. Джерело фінансування активів PKP Polskie Linie Kolejowe за період 2012-2013 років

Висновок. Аналіз функціонування залізниць в умовах конкурентного залізничного ринку показав, що процес розподілу пропускної спроможності залізничної інфраструктури набуває важливого значення. Так, від ефективності та швидкості узгодження доступу до залізничної мережі великої кількості конкуруючих компаній залежать фінансові результати всіх учасників залізничної системи. У цих умовах для залізниць України є очевидною необхідністю розвиток принципово нових методів управління пропускною спроможністю залізничної інфраструктури, що дасть змогу підвищити прибутковість від операційної діяльності компанії, що управляє інфраструктурою.

\section{Список використаних джерел}

1. Мукмінова, Т.А. Ринкова трансформація суб'єктів господарювання на залізничному транспорті [Текст] / Т.А. Мукмінова // Екон.-мат. моделювання соц.-екон. систем. - 2007. - Вип. 12. C. 29-37.

2. Обзор морского транспорта за 2013 год [Текст] / Издание организации объединенных наций. UNCTAD/RMT. Нью-Йорк; Женева, 2013. - 228 с. 
3. Tirole, J. The theory of industrial organization [Text] / Jean Tirole. - MIT Press, 1988. -479 p.

4. Хусаинов, Ф.И. Экономические реформы на железнодорожном транспорте [Текст]: монография / Ф.И. Хусаинов. - М.: Издательский Дом «Наука», 2012. - 192 с.

5. Прохорченко, А.В. Концептуальні підходи до управління пропускною спроможністю залізничної інфраструктури в умовах конкуренції на ринку перевезень [Текст] / А.В. Прохорченко // Залізничний транспорт України. - 2013. - Вип. 3/4. - С. 63-65.

6. Klabes, S.G. Algorithmic Railway Capacity Allocation in a Competitive European Railway Market [Text] / Sebastian Georg Klabes // Fakultat fur Bauingenieurwesen der Rheinisch-Westfalischen Technischen Hochschule Aachen zur Erlangung des akademischen Grades eines Doktors der Ingenieurwissenschaften genehmigte Dissertation. Manuscript. - 2010. - 209 p.

7. Schittenhelm, B. Railway Timetabling Based on Systematic Follow-up on Realized Railway Operations [Text] / B. Schittenhelm, T. Richter - Annual Transport Conference at Aalborg, 2009. - 29 p.

8. Railway Market Analysis [Text] / Bundesnetzagentur für Elektrizität, Gas, Telekommunikation, Post und Eisenbahnen, Bonn. - 2013. - 81 p.

9. An Assessment of Rail Market Operations and Rail Traffic Safety in 2013 [Text] / Departament Regulacji Rynku Kolejowego i Departament Bezpieczeństwa Kolejowego // Urząd Transportu Kolejowego, Warszawa, $2014-143$ p.

10. Polskie Linie Kolejowe S.A. Annual Report 2013 [Text] / Biuro Nieruchomości i Geodezji Kolejowej PKP Polskie Linie Kolejowe S.A., Warszawa, 2014. - 79 p.

$$
\text { Рецензент д-р техн. наук, професор О.М. Огар }
$$

Прохорченко Андрій Володимирович, кандидат технических наук, доцент, кафедра управління експлуатаційною роботою, Український державний університет залізничного транспорту. Тел.: (057) 730-10-88. E-mail: railwayhub@yandex.ua.

Prokhorchenko Andrii Ph.D., Associate Professor, Department of Management of operational work, Ukrainian State University of Railway Transport. Tel.: (057) 730-10-88. E-mail: railwayhub@yandex.ua.

Стаття прийнята 07.07.2015 p. 